\title{
Qualitative and quantitative examination of the proteins of rat uterine luminal fluid during pro-oestrus and pregnancy and comparison with those of serum
}

\author{
M. A. H. Surani \\ Physiological Laboratory, University of Cambridge, Cambridge CB2 3EG, U.K.
}

\begin{abstract}
Summary. Rat serum and uterine luminal proteins at two distinct endocrinological stages were analysed electrophoretically. The quantitative relationships between the major macromolecular fractions were calculated from the densitometer scans. At pro-oestrus there was a marked increase in the total luminal proteins which was probably not due to transudation of serum into the lumen because of the presence of large amounts of two proteins, of approximate mol. wt 125,000 and 130,000, which were not detected in serum. Quantitative estimates of proteins of different molecular weight fractions in the fluids showed that there were considerable differences between the three fluids, indicating that the hormones do not merely induce a free passage of serum proteins into the lumen. On Day 5 of pregnancy there was a considerably lower amount of protein in the uterine lumen and qualitatively these proteins differed from those in serum and the uterine lumen at pro-oestrus.
\end{abstract}

\section{Introduction}

Uterine luminal proteins constitute part of the extracellular environment of the preimplantation blastocyst and appear to influence embryonic cell metabolism and proliferation (Surani, 1975; Webb \& Surani, 1975). The presence and abundance of uterine luminal proteins vary with the concentrations of oestrogen and progesterone (Surani, 1975, 1976; Gore-Langton \& Surani, 1976) and the rat uterus is sensitized by progesterone and oestrogen for blastocyst implantation (Psychoyos, 1973). Oestrogen and progesterone also influence mitosis and orderly recruitment of epithelial and stromal cells before implantation (Tachi, Tachi \& Lindner, 1972; Finn \& Martin, 1974). Oestrogen induces an increase in uterine weight which is restricted in the presence of progesterone (Hsueh, Peck \& Clark, 1975). The regulation of uterine growth and functional differentiation may depend upon the hormonal receptors in the cells and quantitative changes in the receptors are found during different endocrine states (Mester, Martel, Psychoyos \& Baulieu, 1974; Hsueh et al., 1975).

Assuming that some of the uterine luminal proteins are derived from differentiating cells, analysis of uterine fluids could distinguish biochemical markers for the hormone-dependent cytodifferentiation and clarify the molecular events associated with uterine sensitization for implantation. The present study was therefore an evaluation of the qualitative and quantitative differences between serum and uterine luminal fluid in the rat. The reproductive stages chosen for study were pro-oestrus and pregnancy (Day 5) because the steroid levels at these times differ considerably both temporally and quantitatively. Oestradiol levels are 15-20 times higher at pro-oestrus compared with those during pregnancy but the progesterone levels are low at this stage of the oestrous cycle (Yoshinaga, Hawkins \& Stocker, 1969; Schwartz, 1974). In contrast, there is a small and continuous increase in the levels of both oestradiol and progesterone during early pregnancy (Hashimoto, Henricks, Anderson \& Melampy, 1968; Nimrod-Zmigrod, Ladany \& Lindner, 1972).

\section{Materials and Methods}

Fifty Wistar rats (180 g body weight) were kept in artificial light $(05.00-19.30 \mathrm{~h})$. Females were mated, 2-3 per cage, and the presence of spermatozoa in the vaginal smear was taken as Day 1 of pregnancy. Pregnant females were killed at $12.00 \mathrm{~h}$ on Day 5 , the day of embryo implantation in the rat. Vaginal 
smears were taken daily from 30 virgin females for two cycles (5-day cycles) and these females were killed on the morning of pro-oestrus.

\section{Collection of uterine fluids and serum and preparation for electrophoresis}

The animals were decapitated and exsanguinated to minimize contamination of uterine samples with serum. The uterine horns were quickly removed and placed on a filter paper moistened with saline on a glass plate placed on ice. Both horns from each animal were flushed with a total of $0.2 \mathrm{ml} 0.01$ M-phosphate buffer (pH 7.0). Pro-oestrous females were similarly treated except that the uterine fluid $(70-200 \mu l)$ was aspirated before flushing the uterine horns, and the aspirate and flushings were analysed separately. All samples were centrifuged at $12,000 \mathrm{~g}$ for $1 \mathrm{~h}$ to remove any cellular debris and the volume of the supernate was adjusted to contain approximately $100 \mu \mathrm{g}$ protein after estimation of protein content (Lowry, Rosebrough, Farr \& Randall, 1951). Serum was obtained from females at Day 5 of pregnancy and at pro-oestrus and samples containing about $100 \mu \mathrm{g}$ protein were prepared in $0.2 \mathrm{ml} 0.2 \mathrm{M}$-phosphate buffer. To each of these samples, $5 \mu \mathrm{l}$ of a solution was added to give a final concentration in the samples of $0.1 \%$ dodecyl sulphate (Serva, Heidelberg, Germany), 0.14 M-2mercaptoethanol, $0.002 \%$ bromophenol blue and $10 \%$ glycerol. The samples were reduced and denatured to yield protein-dodecyl sulphate complexes by heating to $65^{\circ} \mathrm{C}$ in a water bath for $1 \mathrm{~h}$ (Surani, 1975).

\section{Electrophoretic separation}

Electrophoresis was carried out in $11 \times 0.58 \mathrm{~cm}$ tubes. The running gel, $8.5 \mathrm{~cm}$ long, was made of $7.5 \%$ or $5 \%$ acrylamide (Eastman Kodak, Rochester, New York) in 0.2 M-phosphate buffer (pH 7.2) containing $0.1 \%$ dodecyl sulphate. No stacking gel was used. The reservoir buffer was $0.1 \mathrm{M}$-sodium phosphate buffer (pH 7.2) and $0.2 \%$ dodecyl sulphate. Electrophoresis was continued for 5-8 h (running front to $8 \mathrm{~cm}$ ) at a constant current of $8 \mathrm{~mA} /$ tube.

All gels were stained with coomassie brilliant blue (Sigma, London) $(0.25 \%$ in methanol/acetic acid/water, $5: 1: 5$ by vol.) overnight, and destained by diffusion in a solvent of $7.5 \%$ acetic acid $+5 \%$ methanol. The gel length increased from 8.5 to $9.3 \mathrm{~cm}$ during this procedure.

The standard proteins (bovine serum albumin, ribonuclease, cytochrome $\mathrm{C}$, ovalbumin, chymotrypsinogen $\mathrm{A}$, transferrin and peroxidase) were made up singly or together at a concentration of $10 \mu \mathrm{g}$ each in $0.2 \mathrm{ml}$ phosphate buffer and treated as were the serum and uterine samples. The relative mobilities and molecular weights of the separated proteins were calculated (Weber \& Osborn, 1969) by the formula:

$$
\text { mobility }=\frac{\text { distance of protein migration }}{\text { length of gel after destaining }} \times \frac{\text { length before staining }}{\text { distance of dye migration }}
$$

Densitometer curves were obtained with a Joyce Loebl Chromoscan densitometer and a complementary filter of $595 \mathrm{~nm}$ and specimen drive gear ratio of $1: 3$.

\section{Results}

\section{Qualitative analyses}

The results of electrophoretic analysis of a sample of each of the three fluids on 5 and $7.5 \%$ polyacrylamide gels are shown in Plate 1 and Text-fig. 1 and these results are completely representative of all the results obtained. Analysis of uterine samples from pro-oestrous females and the serum samples gave highly reproducible results, but in a few samples of uterine fluid from pregnant females the lower and higher molecular weight proteins were relatively faintly stained. There were no detectable differences in the serum samples obtained on Day 5 of pregnancy compared with those from females at pro-oestrus.

The aspirated fluids and the flushings obtained from the females at pro-oestrus gave similar results. Pro-oestrous fluid was distinguished by the presence of two proteins of approximate mol. wt 125,000 and 130,000 on $5 \%$ gels. The luminal proteins of pregnant females consisted of a large number of 
PLATE 1

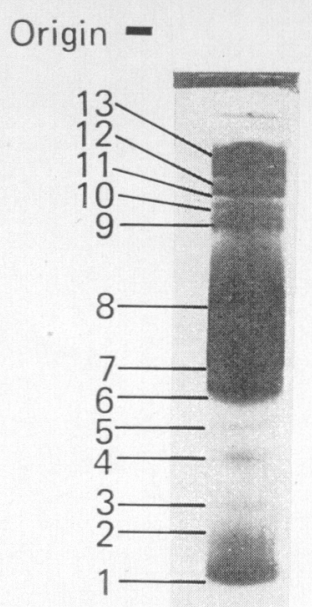

$+$

(a)
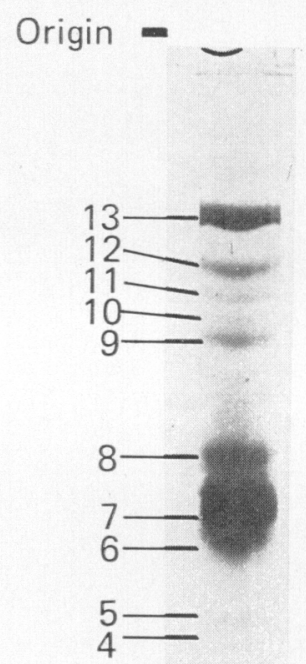

${ }_{2}^{3}=$

$1 \longrightarrow$
$7 \cdot 5 \% \mathrm{gel}$

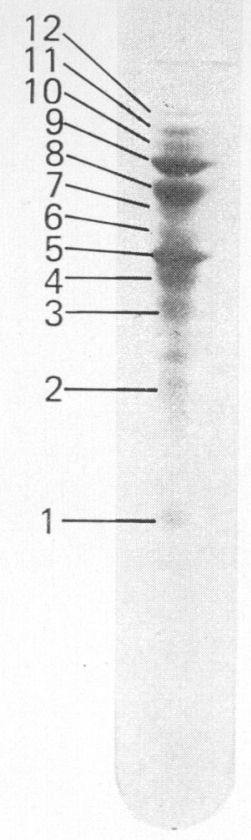

(b)

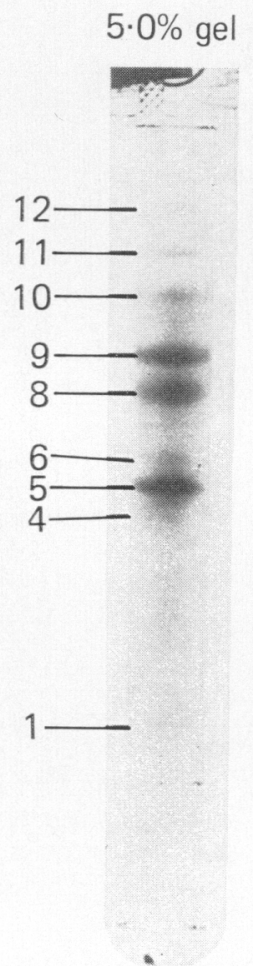

(b)
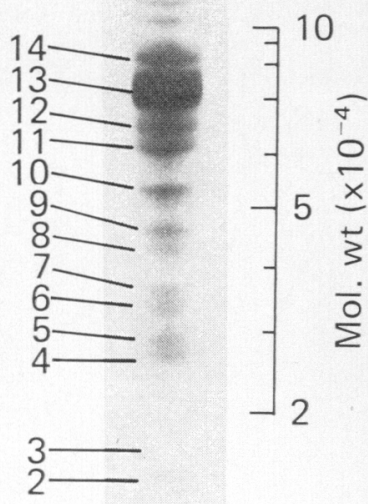

1

(c)

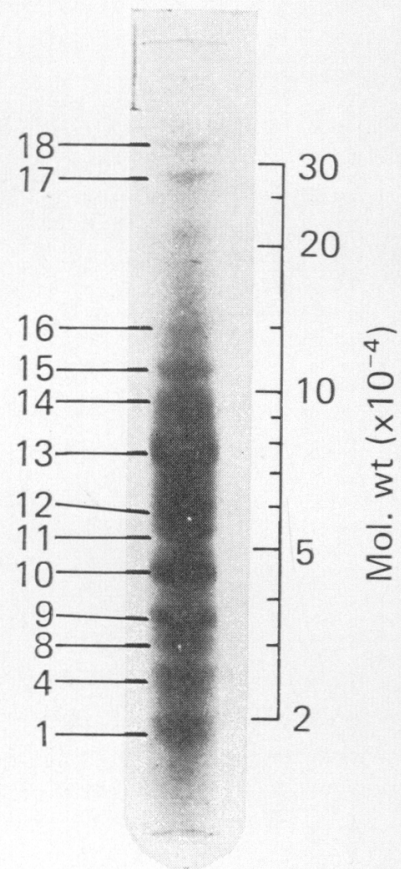

(a)

(c)

Polyacrylamide disc gel electrophoretic analyses on 7.5 and $5.0 \%$ gels of rat serum and uterine luminal proteins. (a) Serum, (b) uterine luminal fluid at pro-oestrus, and (c) uterine luminal fuid at Day 5 of pregnancy. 

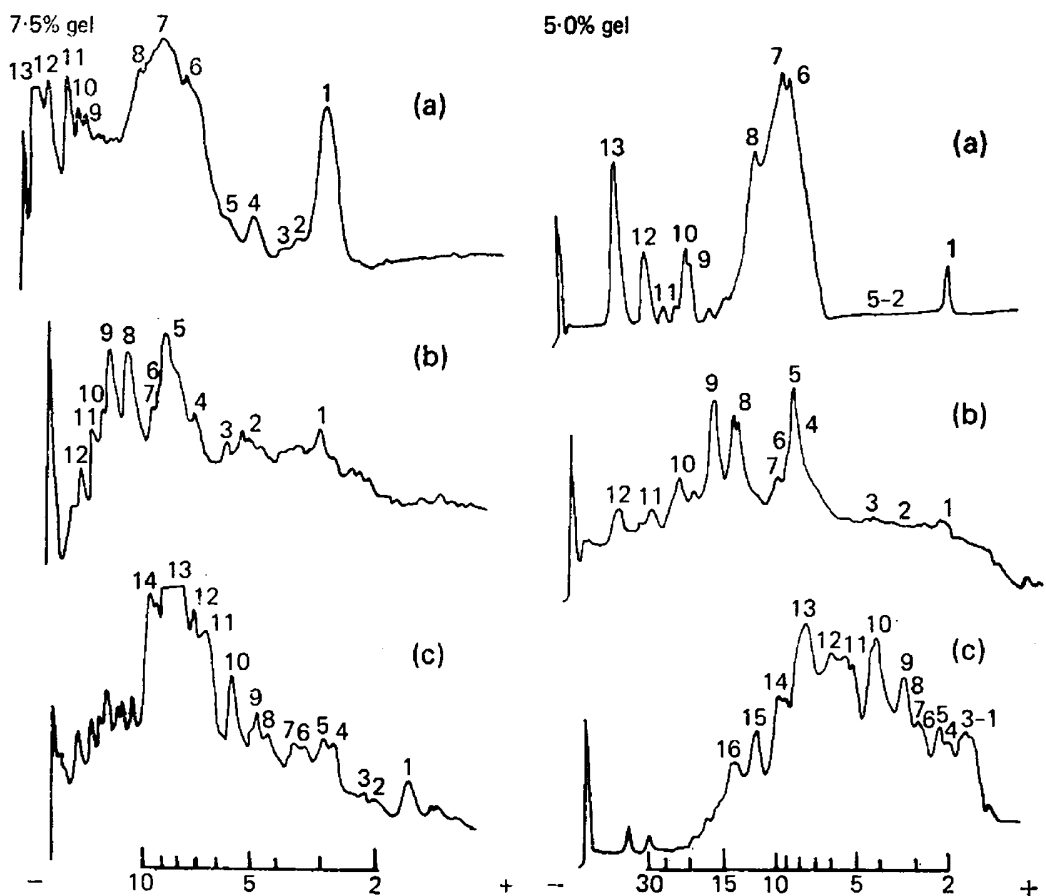

(c)

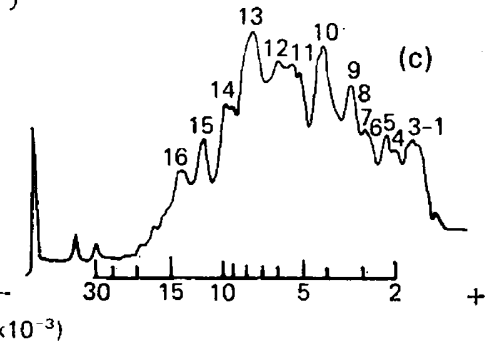

Text-fig. 1. Densitometer scans of the gels shown in Plate 1 in $7.5 \%$ and $5.0 \%$ running gels. (a) Serum, (b) uterine luminal fluid at pro-oestrus, and (c) uterine luminal fluid at Day 5 of pregnancy.

quantitatively meagre, higher molecular weight proteins and were characterized by protein components migrating on either side of a protein of mol. wt 70,000, in addition to a large number of distinct proteins of lower molecular weight. The serum albumin band was usually broad and diffuse compared with the sharp, distinct band in the uterine fluids of similar electrophoretic mobility. This macromolecule in uterine fluids does not necessarily represent serum albumin. The protein bands in the fluids are arbitrarily numbered (Text-fig. 1 and Plate 1) so as not to prejudge their origin or identity and their mobilities on the gels and estimated molecular weights are given in Table 1.

\section{Quantitative estimations}

The total amount of protein in pro-oestrous luminal fluid (aspirated and flushed) was variable (between 450 and $2000 \mu \mathrm{g} /$ female, $\mathrm{N}=15$ ) but was greatly in excess of the mean amount recovered from pregnant females (72.92 $\pm 7 \cdot 6$ (S.E.M.) $\mu \mathrm{g} /$ female, $\mathrm{N}=14$ ).

Densitometer scans (Text-fig. 1) of each gel were divided into three major segments: Fraction HM representing the higher molecular weight proteins $(\geqslant 70,000)$; Fraction $\mathrm{A}$, the distinct protein band of approximate mol. wt 70,000 , which is albumin in serum samples but of unknown nature in the uterine fluids; and Fraction LM containing the lower molecular weight proteins $(\leqslant 70,000)$. The area under each of these segments was determined by calculating the squares on graph paper and was expressed as a \% of the total area under the densitometer scan (Table 2). The quantitative comparisons are based on the assumption that all proteins exhibit an equal affinity for the stain, coomassie blue, and that there is a linear relationship between the amount of protein and the binding of stain. The area occupied by each segment differed in the $5 \%$ and $7.5 \%$ gels because the proteins had migrated further down the gel, thus increasing the area under Fraction HM. These quantitative values do not therefore reflect the true amounts of macromolecules, but the changes in the proportions of each fraction remain similar in both gel concentrations. The HM fraction was the largest in both the serum and pro-oestrous samples whereas Fraction LM was largest for the material from pregnant females. The 
Table 1. Mobilities and estimated molecular weight of proteins detected in uterine fluids and serum of rats

\begin{tabular}{|c|c|c|c|c|c|}
\hline \multirow[b]{2}{*}{$\begin{array}{l}\text { Sample } \\
\text { (no.) }\end{array}$} & \multirow[b]{2}{*}{ Band no. $†$} & \multicolumn{2}{|c|}{$7.5 \%$ gel } & \multicolumn{2}{|c|}{$5.0 \%$ gel } \\
\hline & & Mobility & $\begin{array}{c}\text { Estimated } \\
\text { mol. wt }\left(\times 10^{-3}\right)\end{array}$ & Mobility & $\begin{array}{c}\text { Estimated } \\
\text { mol. wt }\left(\times 10^{-3}\right)\end{array}$ \\
\hline \multirow[t]{13}{*}{ Serum (12) } & 1 & 0.72 & $24 \cdot 5$ & 0.93 & $17 \cdot 0$ \\
\hline & 2 & 0.63 & $30 \cdot 5$ & 0.88 & $20 \cdot 8$ \\
\hline & 3 & 0.60 & $33 \cdot 5$ & 0.81 & $25 \cdot 3$ \\
\hline & 4 & 0.54 & 43.0 & 0.75 & 33.5 \\
\hline & 5 & 0.50 & $50 \cdot 5$ & 0.71 & $39 \cdot 0$ \\
\hline & 6 & 0.35 & $64 \cdot 0$ & 0.61 & $57 \cdot 0$ \\
\hline & $7 \ddagger$ & 0.30 & $72 \cdot 0$ & 0.55 & $73 \cdot 0$ \\
\hline & 8 & $0 \cdot 23$ & $86 \cdot 0$ & 0.50 & 83.0 \\
\hline & 9 & 0.21 & $90 \cdot 0$ & 0.35 & $153 \cdot 8$ \\
\hline & 10 & 0.14 & $110 \cdot 0$ & 0.31 & $182 \cdot 3$ \\
\hline & 11 & $0 \cdot 13$ & $120 \cdot 0$ & 0.29 & $198 \cdot 8$ \\
\hline & 12 & 0.05 & $130 \cdot 0$ & 0.26 & $221 \cdot 0$ \\
\hline & 13 & $0-03$ & $209 \cdot 0$ & 0.20 & $273 \cdot 3$ \\
\hline \multirow{12}{*}{$\begin{array}{l}\text { Pro-oestrous } \\
\text { fluid (15) }\end{array}$} & 1 & 0.67 & $25 \cdot 5$ & 0.90 & $18 \cdot 5$ \\
\hline & 2 & 0.40 & $56 \cdot 5$ & & \\
\hline & 3 & 0.35 & $64 \cdot 0$ & & \\
\hline & 4 & $0 \cdot 30$ & $72 \cdot 0$ & 0.58 & $69 \cdot 0$ \\
\hline & 5 & $0 \cdot 27$ & $76 \cdot 0$ & 0.54 & $74-6$ \\
\hline & 6 & 0.23 & $86 \cdot 0$ & & \\
\hline & 7 & $0 \cdot 21$ & $90 \cdot 0$ & & \\
\hline & $* 8$ & 0.19 & $96 \cdot 0$ & 0.41 & $125 \cdot 5$ \\
\hline & $* 9$ & $0 \cdot 15$ & $105 \cdot 0$ & 0.39 & $130 \cdot 0$ \\
\hline & 10 & $0 \cdot 12$ & 116.0 & $0 \cdot 25$ & 216.8 \\
\hline & 11 & $0 \cdot 10$ & $119 \cdot 0$ & 0.19 & $291 \cdot 3$ \\
\hline & 12 & 0.07 & $120 \cdot 0$ & 0.12 & $376 \cdot 3$ \\
\hline \multirow{18}{*}{$\begin{array}{l}\text { Day } 5 \text { of } \\
\text { pregnancy (24) }\end{array}$} & 1 & 0.94 & $14 \cdot 0$ & 0.91 & $15 \cdot 6$ \\
\hline & 2 & 0.86 & $16 \cdot 7$ & & \\
\hline & 3 & 0.80 & $19 \cdot 4$ & & \\
\hline & 4 & 0.69 & $24 \cdot 0$ & 0.86 & $22 \cdot 3$ \\
\hline & 5 & 0.65 & $29 \cdot 0$ & & \\
\hline & 6 & 0.59 & 33.7 & & \\
\hline & 7 & 0.56 & $36 \cdot 6$ & & \\
\hline & 8 & 0.52 & 40.6 & 0.83 & 26.0 \\
\hline & $* 9$ & 0.48 & $44 \cdot 6$ & 0.80 & $29 \cdot 0$ \\
\hline & ${ }^{*} 10$ & 0.40 & 56.5 & 0.73 & $36 \cdot 5$ \\
\hline & $* 11$ & 0.36 & $62 \cdot 4$ & 0.67 & $45 \cdot 0$ \\
\hline & $* 12$ & 0.34 & $64 \cdot 7$ & 0.62 & 57.0 \\
\hline & 13 & 0.28 & $74 \cdot 4$ & 0.58 & $69 \cdot 0$ \\
\hline & $* 14$ & 0.23 & 86.0 & 0.51 & $85 \cdot 0$ \\
\hline & $* 15$ & & & 0.46 & 105.0 \\
\hline & 16 & & & 0.41 & 125.5 \\
\hline & 17 & & & 0.22 & $250 \cdot 0$ \\
\hline & 18 & & & 0.13 & $362 \cdot 5$ \\
\hline
\end{tabular}

* Denotes some key uterine proteins.

$\dagger$ As indicated in Text-fig. 1 and Plate 1.

$\ddagger$ Position of serum albumin.

relative proportion of Fraction A was greatest in serum but considerably less in both the uterine fluids at 13 to $20 \%$ of the total proteins. However, the total amount of Fraction A in pro-oestrous fluid was calculated to be about $225 \mu \mathrm{g}$ per animal compared with $14.4 \mu \mathrm{g}$ in fluids from pregnant females.

The ratios of areas occupied by each segment in the three fluids reveal the quantitativerelationships between the macromolecules (Table 3). In the pro-oestrous samples the ratio A:HM was the lowest because of the large amounts of the two macromolecules in the higher molecular weight region without a relative increase in $A$. In the samples from pregnant females $A: L M$ was the lowest since this sample 
Table 2. Quantitative distribution (mean \pm S.E.M.) of macromolecules in uterine fluids and serum of rats (no. of samples in parentheses)

\begin{tabular}{|c|c|c|c|c|}
\hline Fraction & $\begin{array}{c}\text { Gel conc. } \\
(\%)\end{array}$ & $\begin{array}{l}\text { Serum } \\
\text { (12) }\end{array}$ & $\begin{array}{l}\text { Pro-oestrous } \\
\text { (15) }\end{array}$ & $\begin{array}{l}\text { Pregnant } \\
\text { (24) }\end{array}$ \\
\hline \multirow[t]{2}{*}{ HM } & 7.5 & $32 \cdot 9 \pm 5 \cdot 2$ & $35 \cdot 5 \pm 5 \cdot 9$ & $25 \cdot 5 \pm 4 \cdot 2$ \\
\hline & $5 \cdot 0$ & $45 \cdot 0 \pm 2.2$ & $58 \cdot 4 \pm 4 \cdot 1$ & $24.4 \pm 1.7$ \\
\hline \multirow{2}{*}{ A } & 7.5 & $42 \cdot 8 \pm 6 \cdot 1$ & $20.6 \pm 4.9$ & $17 \cdot 6 \pm 3.8$ \\
\hline & 5.0 & $40 \cdot 1 \pm 3 \cdot 1$ & $13 \cdot 7 \pm 1 \cdot 3$ & $16 \cdot 6 \pm 1 \cdot 1$ \\
\hline \multirow[t]{2}{*}{ LM } & 7.5 & $24.3 \pm 1.9$ & $43 \cdot 8 \pm 5 \cdot 7$ & $58.4 \pm 3 \cdot 1$ \\
\hline & 5.0 & $14.9 \pm 1.0$ & $27 \cdot 9 \pm 5 \cdot 9$ & $59 \cdot 4 \pm 2 \cdot 3$ \\
\hline
\end{tabular}

Table 3. Ratios (mean \pm S.E.M.) between the major macromolecular fractions in uterine fluids and serum of rats (no. of samples in parentheses)

\begin{tabular}{ccccc}
\hline Ratio & $\begin{array}{c}\text { Gel conc. } \\
(\%)\end{array}$ & $\begin{array}{c}\text { Serum } \\
(12)\end{array}$ & $\begin{array}{c}\text { Pro-oestrous } \\
(15)\end{array}$ & $\begin{array}{c}\text { Pregnant } \\
(24)\end{array}$ \\
\hline A:HM & 7.5 & $1.31 \pm 0.15$ & $0.58 \pm 0.06$ & $0.74 \pm 0.08$ \\
& 5.0 & $0.92 \pm 0.08$ & $0.25 \pm 0.03$ & $0.73 \pm 0.05$ \\
A:LM & 7.5 & $1.78 \pm 0.09$ & $0.48 \pm 0.08$ & $0.31 \pm 0.05$ \\
& 5.0 & $2.96 \pm 0.13$ & $0.50 \pm 0.09$ & $0.28 \pm 0.02$ \\
HM+A:LM & 7.5 & $3.15 \pm 0.20$ & $1.30 \pm 0.15$ & $0.72 \pm 0.12$ \\
& 5.0 & $5.59 \pm 0.57$ & $2.63 \pm 0.50$ & $0.69 \pm 0.30$ \\
LM+A:HM & 7.5 & $2.05 \pm 0.17$ & $1.82 \pm 0.14$ & $3.21 \pm 0.18$ \\
& 5.0 & $1.28 \pm 0.23$ & $0.72 \pm 0.09$ & $4 \cdot 16 \pm 0.28$ \\
\hline
\end{tabular}

contained a large number of lower molecular weight proteins. Other relevant features of the quantitative relationships between the macromolecules can be assessed from the results in Tables 1, 2 and 3.

\section{Discussion}

Previous studies have indicated that about $90 \%$ of the macromolecules in the uterine fluids of nonpregnant females are derived from plasma in the rabbit (Kulangara, 1976) and the rat (Ringler, 1961), but the present results do not confirm this for the rat. This study defines qualitative and quantitative differences between the uterine luminal proteins and serum of the rat and shows that the endocrine state of the females is associated with marked changes in the macromolecular composition of the uterine fluids. The changes in the luminal proteins can be mimicked in ovariectomized females given exogenous hormones: treatment of ovariectomized rats with $2 \mathrm{mg}$ progesterone $+1.0 \mu \mathrm{g}$ oestradiol results in the appearance of luminal proteins which are similar to those found at pregnancy (Surani, 1975), whereas two injections of $1.0 \mu \mathrm{g}$ oestradiol over $48 \mathrm{~h}$ produce protein components similar to those found at pro-oestrus (M. A. H. Surani, unpublished). High plasma concentrations of oestrogen at pro-oestrus cause a substantial increase in the intraluminal proteins which is not due merely to an influx of serum proteins. Previous studies have also shown that high levels of oestrogen cause formation and retention of intraluminal fluid (Armstrong, 1968; Kennedy, 1974) and a substantial increase in the intraluminal protein content (Hasegawa, Sugawara \& Takeuchi, 1973). Presence of high levels of progesterone as found at the time of pregnancy prevents an accumulation of the fluids and an increase in the total proteins (Armstrong, 1968; Hasegawa et al., 1973). Qualitative analyses on 5\% gels revealed the presence of two proteins, of approximate mol. wt 125,000 and 130,000 , in prooestrous fluids and there do not appear to be equivalent components in serum, collected at any stage of pregnancy or the oestrous cycle. If a substantial influx of serum into the lumen had occurred at pro-oestrus, the protein of approximate mol. wt 70,000 in the fluid, which is the electrophoretic equivalent of albumin - the most abundant serum protein, should also have increased. Although the amount of stain binding to the separated proteins may not reflect the true quantities of the individual bands, the gross differences in the proportions of the three major fractions of the fluids do reflect important quantitative shifts. 
The molecular weights of proteins determined in this study should be considered as estimates. The migration of the protein-dodecyl sulphate in gels is dependent on the amount of detergent bound to proteins (Pitt-Rivers \& Impiombato, 1968; Tung \& Knight, 1972) and there is some debate regarding the accuracy with which the molecular weights can be determined with this system (Weber \& Osborn, 1969; Reynolds \& Tanford, 1970; Williams \& Gratzer, 1971; Banker \& Cotman, 1972). The mobilities of the proteins migrating to the middle of the gel are probably more accurately estimated than those which migrate at the ends. This may be one of the reasons for the discrepancies in the mobilities and molecular weight estimates of proteins separated in $7.5 \%$ and $5.0 \%$ gels.

Although this study distinguishes the three fluids quantitatively and qualitatively, further tests are needed to establish conclusively the origin of luminal proteins. For instance, the protein of approximate mol. wt 70,000 in the uterine fluids may be serum albumin or of uterine origin. There could also be selective entry into and sequestration in the uterine lumen of some serum macromolecules present in only small amounts. Selective entry of serum proteins may occur irrespective of the molecular size of the proteins. There may also be some modification in the uterus of the serum proteins before their entry into the lumen. The quantitative shifts in the macromolecular composition of the luminal proteins emphasizes the need to determine not only the biological effects of individual proteins on blastocysts but also the interactive effects of all the luminal macromolecules on blastocysts before implantation, whether these proteins are serum derived or synthesized and secreted by the differentiating uterine cells.

This work was supported by grants from the Medical Research Council and the Ford Foundation. I thank Dr R. G. Edwards for helpful discussions and Andrea Burling for technical assistance.

\section{References}

ARMSTRONG, D.T. (1968) Hormonal control of uterine lumen fluid retention in the rat. Am. J. Physiol. 214, 764-771.

BANKeR, G.A. \& Cotman, C.W. (1972) Measurement of free electrophoretic mobility and retardation coefficient of protein-sodium dodecyl sulfate complexes by gel electrophoresis. J. biol. Chem. 247, 5856-5861.

FINN, C.A. \& MARTIN, L. (1974) The control of implantation. J. Reprod. Fert. 39, 195-206.

Gore-Langton, R.E. \& Surani, M.A.H. (1976) Uterine luminal proteins of mice. J. Reprod. Fert. 46, 271-274.

Hasegawa, Y., Sugawara, S. \& Takeuchi, S. (1973) Studies on the uterine fluid of rat. Effects of oestrogen and gestagen on protein content and disc electrophoretic patterns. Jap. J. Animal Reprod. 19, 73-77.

Hashimoto, A., Henricks, D.M., Anderson, L.L. \& Melampy, R.M. (1968) Progesterone and pregn-4en-20-ol-3-one in ovarian venous blood during various reproductive states in rats. Endocrinology 82, 333-341.

Hsueh, A.J., Peck, E.J. \& Clark, J.H. (1975) Progesterone antagonism of the oestrogen receptors and oestrogen-induced uterine growth. Nature, Lond. 254, 337-339.

KENNEDY, T.G. (1974) Effect of relaxin on oestrogeninduced luminal fluid accumulation in the ovariectomized rat. J. Endocr. 61, 347-353.

KulangarA, A.C. (1976) Maintenance of plasmaderived proteins at much lower concentrations in the uterine lumen of the rabbit : a kinetic study of passage. J. Reprod. Fert. 46, 189-194.
LOWRY, O.H., Rosebrough, N.J., FARR, A.L. \& RANDALL, R.J. (1951) Protein measurements with the Folin phenol reagent. J. biol. Chem. 193, 265-275.

Mester, I., Martel, D., Psychoyos, A. \& Baulieu, E.E. (1974) Hormonal control of oestrogen receptor in uterus and receptivity for implantation in the rat. Nature, Lond. 250, 776-778.

Nimrod-Zmigrod, A., LAdANY, S. \& LindNer, H.R. (1972) Perinidatory ovarian oestrogen secretion in the pregnant rat, determined by gas chromatography with electron capture detection. $J$. Endocr. 53, 249260.

Pitt-Rivers, R. \& Impiombato, F.S.A. (1968) The binding of sodium dodecyl sulphate to various proteins. Biochem. J. 109, 825-826.

Psychoyos, A. (1973) Hormonal control of ovoimplantation. Vitams Horm. 31, 201-256.

REYNOLDS, J.A. \& TANFORD, C. (1970) The gross conformation of protein sodium dodecyl sulfate complexes. J. biol. Chem. 245, 5161-5165.

RiNGLER, I. (1961) Protein composition of rat uterine luminal fluid. Endocrinology 68, 281-295.

SCHWARTZ, N.B. (1974) The role of FSH and LH and of their antibodies on follicle growth and on ovulation. Biol. Reprod. 10, 236-272.

SURANI, M.A.H. (1975) Hormonal regulation of proteins in the uterine secretion of ovariectomized rats and the implications for implantation and embryonic diapause. J. Reprod. Fert. 43, 411-417.

SuRANI, M.A.H. (1976) Uterine luminal proteins at the time of implantation in rats. J. Reprod. Fert. 48, 141145 . 
TACHI, C., TACHI, S. \& LINDNER, H.R. (1972) Modification by progesterone of oestradiol-induced cell proliferation. RNA synthesis and oestradiol distribution in the rat uterus. J. Reprod. Fert.31,5976.

TUNG, J.S. \& KNIGHT, C.A. (1972) Relative importance of some factors affecting the electrophoretic migration of protein in sodium dodecyl sulfatepolyacrylamide gels. Analyt. Biochem. 48, 153161.

WeBB, F.T.G. \& SURAN, M.A.H. (1975) Influence of environment on blastocyst proliferation, differentiation and implantation. In Regulation of Growth and Differentiated Function in Eukaryote Cells, pp.
519-522. Ed. G. P. Talwar. Raven Press, New York.

Weber, K. \& OsBorN, M.J. (1969) The reliability of molecular weight determination by dodecyl sulfatepolyacrylamide gel electrophoresis. J. biol. Chem. 244, 4406-4411.

WILLIAMS, J.G. \& GRATZER, W.B. (1971) Limitations of the detergent-polyacrylamide gel electrophoresis method for molecular weight determination of proteins. J. Chromat. 57, 121-131.

YoshinAGA, K., HAwkins, R.A. \& Stocker, J.F. (1969) Estrogen secretion by the rat ovary in vivo during estrous cycle and pregnancy. Endocrinology 85, 102112.

Received 11 November 1976 